\title{
ASSESSMENT OF WOMEN INVOLVEMENT IN CATFISH (Clarias gariepinus) PROCESSING AND PRESERVATION IN IJEBU-ODOGBOLU LOCAL GOVERNMENT AREA OF OGUN STATE, NIGERIA
}

\author{
"Kayode, A. $\mathrm{O}$ and Awoyemi, A. O \\ Department of Agricultural Extension and Rural Development University of Ilorin, Ilorin. Nigeria. \\ ${ }^{*}$ Corresponding author: toyinkayode2000@yahoo.com; +2348067309397
}

\section{ABSTRACT}

This study assessed the activities of women in processing and preservation of catfish in ljebuOdogbolu Local Government Area of Ogun State. A three-stage random sampling technique was employed to select a total of 120 respondents for the study. The data collected were analysed with both descriptive statistics and correlation model. The mean age of the respondents was 54 years with a mean of nine years of catfish processing and preservation experience. The annual mean income was N107, 587.50. Findings also show that respondents' levels of involvement in processing and preservation methods such as smoking and salting were high. There was a positive and significant relationship between respondents' age ( $r=0.003 ; p=0.034)$, annual income ( $r=$ $0.012 ; p=0.030)$, household size $(r=0.232 ; p=0.011)$ and their level of involvement in catfish preservation at $5 \%$ level of significance. The results of correlation analysis also show that a significant relationship exists between respondents' perceived benefits and their level of involvement in catfish processing and preservation. The study concludes that, although the level of involvement of women in catfish preservation methods was high, low income was realized from the venture when compared with the minimum wage of N18,000 that government workers earn in the study area. It therefore recommends upgrading the methods and facilities used for the preservation and preserving catfish.

Key words: Women activities, Processing, Preservation, Catfish, 


\section{INTRODUCTION}

Fish is a major source of protein for humans and animals. This may be due to its tenderness and easy digestibility (Kumolu-Johnson et al, 2011). Catfish (Clarias gariepinus) suits the tropical region for culture in aquatic environment and provides up to $40 \%$ of animal protein consumed by an average Nigerian (Fagbenro et al., 2010). The Food and Agriculture Organisation (2012) reported that fish accounts for about one-fifth of world total supply of animal protein. Adewumi et al., (2011) confirms that catfish is the most commonly cultivated in Nigeria and this has boosted the growth of aquaculture in the country. African catfish, Clarias gariepinus, is a specie which is extremely hardy and withstands adverse environmental condition and habitat instability. It does not easily succumb to diseases and feeds on all types of bio-wastes. Its growth under natural condition is fast. The predatory, cannibalistic and voracious feeding habit of catfish makes farmers culture them in natural inland freshwater bodies.

Processing of fish starts from the harvesting till the final product is delivered to its consumers. Processing and preservation of fish are of utmost importance as fish is highly susceptible to deterioration. This should, therefore, be done immediately after harvest to prevent economic losses. If fish is sold fresh, preservation methods should be applied to extend its shelf-life. Junaid et al., (2010) noted that spoilage proceeds as a series of complex enzymatic, microbial and chemical changes that begin as soon as the fish dies. Therefore, fish processing and preservation should be carried out mainly to slow down or prevent the enzymatic, microbial and chemical deterioration of fresh fish. According to Akinola et al. (2006) some of the different types of preservation methods employed to arrest fish spoilage include: drying, smoking, freezing, chilling and brining.

Activities of women in catfish processing and preservation have become more relevant in eradicating poverty promoting food security in Nigeria. Oluwatoyin et al., (2013) reported that women are integral part of fishing business and according to Odili et al., (2012) women spend prolong hours daily in fishing related activities for which they receive very little or no assistance from non-governmental organizations or other relevant organizations. They are directly and vigorously involved with their capital in the coordination of the fisheries chain, from production to sale of fish.

However, significant contributions of women in post-harvest fish handling have been underestimated, under-documented, under-appreciated, and under-supported, by prevailing economic policies and other developmental programmes (Omorodion, 2004). There is therefore the need for adequate information on processing and preservation of catfish among women who are mostly involved in catfish processing and preservation activities. It is against this background 
that this study was conducted to assess the activities of women in catfish processing and preservation. Specifically, the study sought to: (i) identify the existing catfish preservation and processing methods utilized in the study area; (ii) examine the level of involvement of women in catfish processing and preservation; and to (iii) identify the perceived benefits of catfish processing and preservation among women in the study area

Hypotheses of the Study

$\mathrm{HO}_{1}$ : There is no significant relationship between some selected socio-economic characteristics of the respondents and their level of involvement in catfish preservation methods.

$\mathrm{HO}_{2}$ : There is no significant relationship between perceived benefits and level of involvement in catfish preservation methods.

\section{METHODOLOGY}

\section{The Study Area}

This study was carried out in ljebu Odogbolu Local Government Area of Ogun State. The study area is one of the 20 Local Government Areas in the state. The Local Government Area has its headquarters at ljebu Odogbolu, which is located between Longitudes 6046' and latitude 3048'. It shares boundaries with ljebu East, ljebu North, ljebu North-East and ljebu ode. The popular income-generating activities in the study area include making of clothing materials (batik commonly called Adire) and agricultural activities such as growing of rice, maize, cassava, yam and banana, fish farming and livestock production.

\section{Sampling Procedure and Sample Size}

The population of the study comprised all women who were involved in processing and preservation of catfish as a means of livelihood in ljebu Odogbolu Local Government Area of Ogun State. A three-stage random sampling procedure was employed in the study. The first stage involved the random selection of about $10 \%$ of the 84 communities in Odogbolu Local Government Area to give a total of eight (8) communities. The communities were Odo oba, Araromi, Aiyepe, Odogbolu, Ogoji, Ogudu, Imodi-ljesa and Itanrin. In the second stage, with the aid of the local leaders and extension agents in the communities, a list of catfish processors was generated which forms the sample frame. In the third stage $20 \%$ of the processors were randomly selected from each of the communities to give a total of one hundred and twenty (120) respondents. The procedure is summarized in Table 1. 
Table 1: Sampling Procedure and Sample size

\begin{tabular}{clccc}
\hline $\begin{array}{c}\text { Number of villages } \\
\text { in Odogbolu LGA }\end{array}$ & $\begin{array}{l}\text { Random selection } \\
\mathbf{1 0 \%}\end{array}$ & $\begin{array}{l}\text { Sample } \\
\text { frame }\end{array}$ & $\begin{array}{c}\text { Sample size } \\
\text { Random selection of 20\% }\end{array}$ & TOTAL \\
\hline & Odo oba & 112 & 22 & \\
& Araromi & 75 & 15 & \\
& Aiyepe & 65 & 13 & 120 \\
& Odogbolu & 100 & 20 & \\
& Ogoji & 49 & 10 & \\
& Ogudu & 80 & 16 & \\
& Imodi-ljesa & 70 & 14 & \\
& Itanrin & 50 & 10 &
\end{tabular}

\section{Data Analysis}

Data were collected through a structured interview schedule and analysed with descriptive statistics such as frequency, percentages, mean, and standard deviation. Pearson's Product Moment Correlation was used to test the hypotheses of the study.

\section{Measurement of Variables}

In order to determine the level of involvement in Catfish Preservation Methods among Women in the study area, A four-point Likert type rating scale of very often $=4$, often $=3$, rarely $=2$, and never $=1$ was used to measure their responses. The mean cut-off mark was calculated by adding $4+3+2+1=10$ divided by 4 to give 2.5 . Any mean score less than 2.5 is considered as low involvement while any mean equal or greater 2.5 is considered as high involvement in catfish preservation methods.

Farmers' perceived benefit was measured on a four-point Likert type scale. A list of perceived benefits statement of involvement in catfish preservation method was drawn. Respondents were asked the extent to which they agreed or disagreed to the statement. The scale was graduated as follows:

Strongly agree (4), Agree (3), Disagreed (2) strongly disagreed (1). The scores were aggregated and converted to mean for individual responses. For the purpose of the study, mean scores less than 2.5 were considered as not beneficial to the respondents while those that were equal or higher than 2.5 were considered as perceived benefits to the respondents. 


\section{RESULTS AND DISCUSSION}

\section{Socioeconomic Characteristics of the Respondents}

Table 2 shows the socioeconomic characteristics of the women that are involved in catfish processing and preservation. The mean age of the women was 53.7 years. The implication of this is that the women are middle aged, energetic, still in their productive age and mature enough to undertake the activities involved in fish processing and preservation efficiently. This corroborates the findings of Alawode et al. (2014) who reported that most adults make fish farming a reliable source of income after retirement. The mean household size of the respondents was six persons. This indicates that they had average household size and can use family labour to reduce the cost of labour. Also, the mean years of schooling of the respondent was found to be 5.48 years with $99.2 \%$ of them acquiring primary education. This is an indication that respondents' literacy level is low and needs to be improved on, since high literacy level will help to improve practices related to the processing and preservation of catfish. This agrees with the findings of Kolawole et al., (2010) that majority of the sampled women, who were engaged in fish processing and preservation had only primary education. This result is however at variance with the findings of Onuche et al., (2015) that catfish farmers are generally well educated.

Also, the mean years of processing preservation of catfish was 8.7 years. This implies that the respondents were highly experienced in processing and preservation of catfish. The mean annual income realized from processing and preservation of fish was N107, 587.50 which was about $\mathrm{N} 9,000$ per month. This indicates that respondents' income from fish processing and preservation in the study area was low when compared to the $\mathrm{N} 18,000$ a government worker would earn as minimum wage in the study area. This corroborates the findings of Adefalu et al (2013) that the mean income of rural farmers in livestock production was lower than the minimum wage $(\mathrm{N} 18,000)$ of the Nigerian civil service. The implication of this low income is that women may likely be involved in other secondary occupation in order to increase their sources of income and this may negatively affect their dedication to fish processing and preservation 
Table 2: Distribution of Respondents According to their Socio-economic Characteristics

\begin{tabular}{|c|c|c|c|c|}
\hline Variables & $\begin{array}{l}\text { Frequency } \\
(n=120)\end{array}$ & Percentages & Mean & SD \\
\hline \multicolumn{5}{|l|}{ Age (Years) } \\
\hline$\leq 30$ & 1 & 0.8 & 53.68 & 10.07 \\
\hline $31-40$ & 14 & 11.7 & & \\
\hline $41-50$ & 34 & 28.4 & & \\
\hline $51-60$ & 43 & 35.8 & & \\
\hline$>60$ & 28 & 23.3 & & \\
\hline \multicolumn{5}{|l|}{ House hold size (Person) } \\
\hline $1-5$ & 98 & 81.7 & & \\
\hline 6.10 & 20 & 16.7 & 5.92 & 2.64 \\
\hline 11 and above & 2 & 1.6 & & \\
\hline \multicolumn{5}{|l|}{ Years of formal education } \\
\hline $1-6$ & 119 & 99.2 & 5.48 & 2.36 \\
\hline $7-12$ & 1 & 0.8 & & \\
\hline Processing \& & & & & \\
\hline \multicolumn{5}{|l|}{ Preservation Experience (Years) } \\
\hline$<10$ & & & & \\
\hline $11-20$ & 85 & 70.8 & & \\
\hline $21-30$ & 33 & 27.5 & 8.7 & 3.26 \\
\hline$>30$ & 2 & 1.7 & & \\
\hline $\begin{array}{l}\text { Annual Income from catfish } \\
\text { processing and Preservation (\#) } \\
<50,000\end{array}$ & 37 & 30.8 & & \\
\hline $50,000-100,000$ & 59 & 49.2 & $\begin{array}{l}107,587 . \\
50\end{array}$ & 107,203 \\
\hline$>100,000$ & 24 & 20.0 & & \\
\hline
\end{tabular}

Source: Field Survey, 2019 


\section{Procedure/steps for Processing of Catfish by the Women}

Table 3 shows the distribution of the respondents according to the various steps involved in catfish processing. Processing of catfish starts immediately after harvesting of the catfish by farmers or purchase for non-farmers as the case may be. The results show that virtually all the steps were being practiced by the women. Washing of fish (after slaughtering) with warm water and salt $(100 \%)$ is common among the women in the study area. This might be because of the slimy flaky flesh of catfish which when washed with salt and warm water reduces or remove the slim from the catfish. Other steps such as folding of the fish (89.1\%), maintaining proper hygiene (88.3\%) and fortification with Moringa leaves which is done in order to increase the longevity and flavouring of fish taste has $78.3 \%$ women involved in the procedure.

Table 3: Procedure/steps for processing of catfish by women in the Study Area

\begin{tabular}{lll}
\hline Procedure/steps involve in fish processing & Frequency & Percentage \\
\hline Washing of fish with warm water and salt & 120 & 100 \\
Folding of fish & 107 & 89.1 \\
Washing of tools before and after use & 97 & 80.8 \\
Maintaining Proper Hygiene & 106 & 88.3 \\
Sourcing/procurement of fish & 42 & 35.0 \\
Fortification with Moringa leaves & 94 & 78.3 \\
Sorting and grading & 50 & 41.6 \\
\hline
\end{tabular}

Source: Field Survey 2019

\section{Catfish Preservation Methods by the Respondents}

Table 4 shows the distribution of the women according to their preservation methods. The result shows that the majority of the women (92.5\%) used smoking method in preserving catfish in the study area. This is in line with George et al. (2013) and Kolawole et al. (2010) who reported that smoking of catfish is most widely adopted as preservation method among fish processors. The result also reported that drying with local oven (75.8\%) is prevalent among the women in the study area. This may be as a result of the fact that the local oven, according to the respondents, was very simple in design and construction. Practices such as canning, and air-drying were not common among the respondents which may be due to some technical know-how involved in the practice. 
Table 4: Catfish Preservation Methods by Women in the Study Area

\begin{tabular}{llll}
\hline Preservation Methods & Frequency & Percentage & Rank \\
\hline Smoking & 111 & 92.5 & $1^{\text {st }}$ \\
Air-drying cooling & 56 & 46.6 & $7^{\text {th }}$ \\
Freezing and Chilling & 83 & 69.1 & $3^{\text {rd }}$ \\
Irradiation & 74 & 61.6 & $5^{\text {th }}$ \\
$\begin{array}{l}\text { Curing of catfish through the addition of } \\
\text { chemicals such as salt, sugar or acids }\end{array}$ & 83 & 69.1 & $3^{\text {rd }}$ \\
$\begin{array}{l}\text { Drying with local oven } \\
\text { Canning }\end{array}$ & 91 & 75.8 & \\
\hline
\end{tabular}

Source: Field Survey, 2019.

\section{Level of involvement in catfish Preservation Methods}

Table 5 shows the level of involvement of women in catfish preservation activities. The result revealed that smoking ranked first $(\bar{x}=3.72)$, next to it is salting $(\bar{x}=3.65)$ followed by drying with local oven $(\bar{x}=3.60)$, and chilling and freezing $(\bar{x}=3.63)$.

Table 5: Level of involvement in Catfish Preservation Methods among Women in the Study Area

\begin{tabular}{lllllll}
\hline Preservation Methods & $\begin{array}{l}\text { Very often } \\
\mathbf{F}(\%)\end{array}$ & $\begin{array}{l}\text { Often } \\
\mathbf{F}(\%)\end{array}$ & $\begin{array}{l}\text { Rarely } \\
\mathbf{F}(\%)\end{array}$ & $\begin{array}{l}\text { Never } \\
\mathbf{F}(\%)\end{array}$ & M.S & Rank \\
\hline Smoking & $87(72.5))$ & $11(9.2)$ & $13(10.8)$ & $9(7.5)$ & 3.72 & 1 st \\
Salting & $87(72.5)$ & $25(20.8)$ & $7(5.8)$ & $1(0.8)$ & 3.65 & 2 nd \\
Drying with local oven & $81(67.5)$ & $34(28.3)$ & $1(0.8)$ & $4(3.3)$ & 3.60 & 3 rd \\
Freezing/Chilling & $59(49.2)$ & $35(29.2)$ & $21(17.5)$ & $5(4.2)$ & 3.23 & 4 th \\
Air-drying cooling & $36(30)$ & $51(42.5)$ & $16(13.3)$ & $17(14.2)$ & 2.88 & 5 th \\
Irradiation & $26(21.6)$ & $22(18.3)$ & $14(11.6)$ & $58(48.3)$ & 1.74 & $6^{\text {th }}$ \\
Canning & $10(8.3)$ & $17(14.2)$ & $41(34.2)$ & $52(43.3)$ & 0.97 & $7^{\text {th }}$ \\
\hline
\end{tabular}

Source: Field Survey, 2019. 
The grand mean score of women involvements in catfish was 2.5, indicating that women in the study area were more involved in catfish preservation methods such as smoking, salting, drying with local oven and freezing of catfish than other methods. This result is in line with Omotesho et al. (2019), George et al. (2013) and Kolawole et al. (2010) as they infer that smoking is the most affordable and widely used preservation method among fish processors.

\section{Categorization of Women in their Level of Involvement in Catfish Preservation Methods}

Table 6 shows categorization of level of involvement in catfish preservation among the women in the study area. The table indicates that the category of high level of involvement in catfish processing and preservation methods was evident among the women. The results imply that in spite of the low income realized from catfish processing and preservation (see Table 2), the level of involvement of the women in this activity is high. These results contradict the findings of Akinpelu et al. (2013) who reported that the female are less involved in catfish preservation which may be due to domestic and care giving roles that women also perform at homestead.

Table 6: Categorization of Respondents based on their Level of Involvement in Catfish Preservation Methods

\begin{tabular}{llll}
\hline & Frequency & Percentage & Mean \\
\hline Low $(<2.00)$ & 0 & 0 & \\
Fair $(2.00-2.99)$ & 3 & 2.5 & 3.66 \\
High $(>2.99)$ & 117 & 97.5 & \\
\hline
\end{tabular}

\section{Source: Field Survey, 2019}

\section{Perceived Benefits of Catfish Processing and Preservation}

Table 7 shows the results on the major perceived benefits of catfish processing and preservation by the respondents of which to reduce the effects of microbial spoilage of catfish (with the mean score of 3.69) is ranked 1st, followed by enhancing desirable taste and flavour with a mean score of 3.64 and it is ranked 2 nd. Another benefit of catfish processing and preservation is to increase the shelf life of catfish. This has a mean score of 3.58 and is ranked the $3 \mathrm{rd}$. Enhancing the nutritive value and promoting digestibility of catfish is another benefit of catfish processing and preservation. It has a mean score of 3.53 and its ranked 4th, followed by increment in the biological value during consumption of catfish, which has a mean score of 3.51 and is ranked 5 th. Another perceived benefit of catfish processing and preservation is that it has low cholesterol content with a mean 
score of 3.47 and it is ranked 6th. These results indicates that the respondents are aware of the benefits of catfish processing and preservation and they derive benefits from the activities.

Table 7: Perceived Benefits of Catfish Processing and Preservation among Respondents

\begin{tabular}{|c|c|c|c|c|c|c|}
\hline Perceived Benefits & $\begin{array}{l}\text { S.A } \\
F(\%)\end{array}$ & $\begin{array}{l}A \\
F(\%)\end{array}$ & $\begin{array}{l}\text { D } \\
F(\%)\end{array}$ & $\begin{array}{l}\text { S.D } \\
F(\%)\end{array}$ & MS & Rank \\
\hline $\begin{array}{l}\text { Reduce the effects of microbial } \\
\text { spoilage }\end{array}$ & $85(70.8)$ & $34(28.3)$ & $0(0)$ & $1(0.8)$ & 3.69 & $1^{\text {st }}$ \\
\hline $\begin{array}{l}\text { Enhances desirable taste when } \\
\text { such fish is smoked and dried }\end{array}$ & $81(67.5)$ & $35(29.2)$ & $4(3.3)$ & $0(0)$ & 3.64 & $2^{\text {nd }}$ \\
\hline Increases the shelf life of catfish & $71(59.2)$ & $48(40)$ & $1(0.8)$ & $0(0)$ & 3.58 & $3^{\text {rd }}$ \\
\hline $\begin{array}{l}\text { Enhances the nutritive value } \\
\text { and promotes digestibility }\end{array}$ & $64(53.3)$ & $54(45)$ & $2(0)$ & $1(0.7)$ & 3.53 & 4th \\
\hline $\begin{array}{l}\text { Increases the biological value } \\
\text { durin7 consumption }\end{array}$ & $66(55)$ & $49(40.8)$ & $5(4.2)$ & $0(0)$ & 3.51 & 5 th \\
\hline It has low cholesterol content & $57(47.5)$ & $62(51.7)$ & $1(0.8)$ & $0(0)$ & 3.47 & 6th \\
\hline
\end{tabular}

(SD=Strongly Disagreed, $\mathrm{D}=$ Disagreed, $\mathrm{A}=$ Agreed, $\mathrm{SA}=$ Strongly Agreed)

\section{Source: Field Survey, 2019.}

Table 8 shows the correlation analysis between some selected socio-economic characteristics of the respondents and level of involvement in catfish processing and preservation. It shows that the age of the respondents $((r=0.009 ; p=0.034))$ had a significant relationship with the level of involvement. Also, the annual income of the respondents $(r=-0.012 ; p=0.030)$ had a significant relationship with the level of involvement. Also, household size of the respondents $(r=0.232$; $p=0.011$ ) also had a significant relationship with the level of involvement. This is expected because large household increases the availability of cheap labour for catfish preservation. On the contrary, the years of schooling of the respondents had a negative significant relationship with the level of involvement in catfish processing and preservation. This implies that the more learned women were not involved in catfish preservation in the study area. This may be due to preference for other jobs, such was white collar jobs or more lucrative jobs. 
Table 8: Correlation Analysis Showing the Relationship between Socio-Economic Characteristics \& the Level of Involvement in Catfish Preservation Methods

\begin{tabular}{llll}
\hline $\begin{array}{l}\text { Socio-economic characteristics } \\
\text { the respondents }\end{array}$ & $\mathbf{r}$-value & $\mathbf{p}$-value & Decision \\
\hline Age & $0.003^{* *}$ & 0.034 & Significant \\
Years of schooling & -0.095 & 0.256 & Not Significant \\
Annual income & $0.012^{* *}$ & 0.030 & Significant \\
Household size & $0.232^{* *}$ & 0.011 & Significant \\
\hline
\end{tabular}

${ }^{* *}$. Correlation is significant at the 0.05 level (2-tailed).

Source: Field survey, 2019.

Table 9 shows the result of correlation analysis between perceived benefits and level of involvement in catfish processing and preservation. Results reveal that there is a relationship between these two variables. The positive relationship implies that the more the respondents' benefits from catfish processing and preservation, the more they are involved in it. That is, respondents that benefit less from processing and preservation involve less likewise.

Table 9: Result of the Correlation Analysis between Perceived Benefits and Level of Involvement in Catfish Processing and Preservation Methods

\begin{tabular}{lll}
\hline & Perceived Benefits & Level of involvement \\
\hline Perceived Benefits & 1 & $0.412^{* * *}$ \\
Level of involvement & $0.412^{* * *}$ & 1 \\
\hline
\end{tabular}

***. Correlation is significant at the .01level (2-tailed)

Source: Field survey, 2019.

\section{CONCLUSION AND RECOMMENDATIONS}

Based on the findings of this study, it can be concluded that the level of involvement of women in catfish processing and preservation in the study area was high in spite of the low income realized from it. Their increasing level of involvement could be as a result of other perceived benefits derived from catfish preservation. Also, the age of respondents, annual income, and household size significantly influence their level of involvement in catfish processing and preservation. This study, therefore, recommends upgrading of the methods and facilities used for processing and preserving catfish. 


\section{REFERENCES}

Adefalu, L.L., Usman, B.O., Omotesho, K.F., Aderinoye-Abdulwahab, S.A. \& Olateju, O.A. (2013). Perceived causes of livestock involvement in Road accident: Threat to livestock Production among women in Oyo state. Agrosearch, 13(2), 12-19.

Adewumi, A. A. \& Olaleye, V. F. (2011). Catfish culture in Nigeria: Progress, prospects and problems. African Journal of Agricultural Research, 6(6), 1281-1285

Akinola, O.A., Akinyemi A.A., Bolaji, B.O. (2006): Evaluation of traditional and solar drying system towards enhancing fish storage and preservation in Nigeria. Journal of Fisheries International, 1, 44-99.

Akinpelu O.M, Ayeloja A.A, George F.O.A, Adebisi G.L, \& Jimoh W.A, (2013). Gender Analysis of Processing Activities among Commercial Catfish Processors within Ibadan Metropolis, Oyo State South-Western Nigeria. Journal of Aquaculture Research and Development, 4, 176

Alawode, O. O., \& Jinad, A. O. (2014). Evaluation of Technical Efficiency of Catfish Production in Oyo State: A Case Study of Ibadan Metropolis. Journal of Emerging Trends in Educational Research and Policy Studies. JETERAPS, 5(2), 223-231

Fagbenro, O.A, Jegede, T. and Fasasi. O.S. (2010): Tilapia aquaculture in Nigeria. Applied Tropical Agriculture, 15, 49-55.

Food and Agriculture Organization (2012). The State of Food Insecurity in the World. Food and Agriculture Organization of the United Nations, Rome (2012)

George F.O.A., Ogbolu A.O., Okunade O.A., Akintayo I.A., Odusanya F.A. \& Odunlate D.0.O (2013). Fish processing technologies in Eti osa Local Government Area of Lagos state, Nigeria. Proceedings of $28^{\text {th }}$ FISON Annual conference Nov, 25-28 2013

Junaid, S. A. Olauboin, F. \& Olabode, A.O. (2010). Mycotic contamination of stock fish sold in Jos, Nigeria. Journal of Yeast and Fungal Research, 1(7), 136 - 141.

Kolawole D.O., Williams S.B. \& Awulola A.F., (2010). Indigenous fish processing and Preservation practices amongst women in Southwestern Nigeria. Indian Journal of Traditional Knowledge, $9(4), 668-672$.

Kumolu-Johnson C.A., \& Ndimele, P.E. (2011). Effect of salting and sun--drying on the shelf -life of Clarias gariepinus. Journal Resources, Rev-sciences, 2, 21-25.

Odili, O.E., Nwabeze G.O., Tafida, A.A., \& Chilaka, M. (2012). Contribution of women to fisheries development in Nigeria: A review. In: Proceedings of the 27th Annual Conference and Biennial General Meeting of the Fisheries Society of Nigeria. Held in Bayelsa, 25 - 30 November 2012. pp 435-438. 
Oluwatoyin D.K., Stella B.W. \& Awojola A.F. (2010). Indigenous fish processing and preservation practices among women in south-western Nigeria. India Journal of traditional Knowledge, 9 , 668-672.

Omorodion, F. I. (2004). The Impact of Petroleum Refinery on the Economic Livelihoods of Women in the Niger Delta Region of Nigeria. A Journal of Culture and African Women Studies, 6, 19.

Omotesho O. A., Adenuga A. H., Nurudeen A. S., \& Olaghere I. L. (2019). Smoking kiln technology for catfish processing: an assessment of its acceptability and willingness to pay: Paper presented at the 6th African Conference of Agricultural Economists, Sept. 23-26, 2019, Abuja, Nigeria

Onuche, U., Ali, S.O., \& Isaac J.T. (). Technical Eficiency Estimation and the role of formal education: Evidence from catfish firms in ljumu LGA of Kogi state, North central, Nigeria. Agrosearch 15(2) 107-117. 